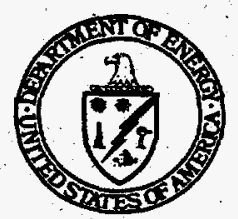

\title{
RCRA Facility Investigation
}

\section{BACKGROUND:}

\begin{abstract}
The Hazardous and Solid Waste Amendments of 1984 (HSWA) broadened the authorities of the Resource Conservation and Recovery Act (RCRA) by requiring corrective action for releases of hazardous wastes and hazardious constituents at treatment, storage, and disposal (TSD) facilltes. The goal of the corrective action process is to ensure the remediation of hazardous constituent reloases associatod with TSD facilitios. Under Sectjon 3004 (u) of RCRA, operating permits issued to TSD facllities mustaddress correctlve actions for all releases of hazardous waste and hazardous constituents from any solld waste management unit (SWMU) regardless of when the waste was placed in such unit. Under RCRA Section 3008(h), the Environmental Protection Agency (EPA) may issue administrative orders to compol corrective action at facillties authorized to operate under RCRA Section
\end{abstract} 3005(e) (l.e., interm status facillties).

A SwMU is defined under 40 CFR 264.501 of the proposed 40 CFR Subpart S as "...any discernible unit at which solid wastes have been placed at any time, regardiuss whether the unlt wes letended for the management of solid or hazardous waste. Such units include any area at a facillty into which solid wastes have been routinely and systematically released...." A release is defined in the proposed 40 CFR 264.501 as "....any spilling, leaking, pouring, emitting, emptying, discharging, injecting, pumpling, escaping, leaching, dumping, or disposing of hazardous wastes (including hazardous constituents) Into the environment...."

The process of implementing the Corrective Action Program involves the following four steps, in order of implementation; 1) RCRA Facility Assessment (RFA); 2) RCRA Facilty Investigation (RFI); 3) the Correctlve Measures Study (CMS); and 4) Corrective Measures Implementation (CMI). EPA or the authorized State would require an RFI if the RFA indicated that a release of a hazardous waste or a hazardous constituent from a SWMU was tikely to have occurred, to be occurring or, in certain limited clrcumstances, is Ilkely to occur. Usually the RFI is required elther under a permit schedule of compllance or in a 3008(h) enforcement order issued by the regulatory agency. The RFI determines the nature; extent; and rate of migration of contaminant releases; determines the contamination source(s); and provides sufficient data to choose approprate response actlons. Investigations to determine releases of concern can range from emall, speclfic activities to complex multimedia studies.

STATUTE:

RCRA as amended by HSWA.

REGULATIONS: . Proposed 40 CFR 264 Subpart $S$ (55 FR 30798, July 27, 1990)

REFERENCE:

1. "RCRA Corrective Actions at Fedoral Facilities," U.S. Environmental Protection Agency, OSWER Directlve 9502.03, 1986.

2. "RCRA Corrective Action Plan,"Interlm Final, U.S. Environmental Protection Agency, OSWER Directive 9902.3, 1988.

3. "RCRA Facillty Investig OSWER Directlve 9502.80-6C, 1989.

4. "RCRA Corrective Action Program Gulde - Itterim Gúldance," U.S. Department of Enérgy, Otfice of Environmental Guidance, RCRA CERCLA Division, Guidance Manual, DOEJEH-0323, May, 1993.

5. "Managing the Corrective Action Program for Environmental Results: The RCRA Stablization Etfort" U.S. Environmental Protection Agency, OSWER Memorandum to Region I-X RCRA Wasto Management Directors, October 25, 1991.

6. "Corrective Action Management Units and Temporary Units; Corrective Action Provisions; Final Rule," 58 FR 3658 , Fobruary 16, 1993.

\section{What is an RFI?}

The RFI is the second step of the RCRA corrective action process, and is taken after an RFA has been conducted. As described under proposed 40 CFR Parts 264.510 through 264.513, the RFI is a detailed investigation to determine the nature, extent, and migration rate of a release of hazardous waste or hazardous constituents, and to provide informationnecessary for developing a strategy for addressing contamination. The RFI is a focused investigation that is designed to characterize releases from individual SWMUs rather than a characterization of the entire facility.

\section{DISTRIBUTION OF THIS DOCUMENT IS UNLIMTED dS}

The need for an RFI is determined based on the RFA report or other information, such as preliminary assessment or site inspection reports under the Comprehensive Environmental Response, Compensation, and Liability Act of 1980(CERCLA); interim measures reports; or records of releases that have occurred at the facility.

The RFI is usually planned in phases. Each phase has established criteria that provide an opportunity for the requirement for an RFI to be terminated if the results of the investigation demonstrate that a release has not occurred at the facility or that there is minimal potential for future releases.

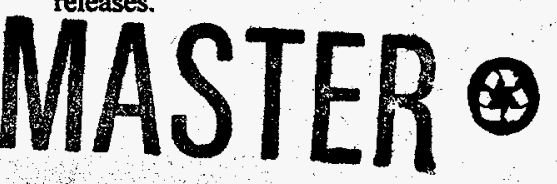

Printed on Recycled Paper 


\section{Who conducts the RFI?}

The RFI is performed by the facility owner or operator, who develops and submits an RFI work plan to EPA or an authorized State, describing the methodology to be used to investigate and characterize the release. EPA or the authorized State oversees the process. Usually, the RFI is required under a permit schedule of compliance or an enforcement order (i.e., a RCRA Section 3008(h) Order) issued by the regulatory agency.

\section{What are the objectives of an RFI and what does it require?}

The objective of an RFI is to determine the nature and the extent of releases of hazardous waste or hazardous constituents from SWMUs at the facility and to gather all necessary data to support the CMS. Conducting an RFI requires the following:

Negotiating requirements and permit conditions with EPA or the authorized State;

- Evaluating existing information to assist in developing a detailed plan for the RFI;

a Considering establishing corrective action management units (CAMUs), where appropriate;

- Continually evaluating the data collected during the RFI;

- Evaluating data collected during an interim CMS (if one was required); and

- Developing a detailed report, with recommendations for further action, for submission to EPA or the authorized State.

\section{What information is presented in an RFI report?}

The proposed 40 CFR Subpart S rule does not provide a specific format for the RFI report. However, the RFI report must document the process and findings of the investigation and provide information to support subsequent decisions. The following elements are typically required:

a A brief discussion of the facility history;

- A brief discussion of the current conditions and operations at the facility, including the terms of the permit, order, or Federal Facility Compliance Agreement;

a A discussion of the objectives established for the RFI during the scoping process, including the data quality objectives established for the investigation;

- A detailed discussion of the technical requirements of the investigation;

A A description and summary of interim CMS activities conducted concurrently with the RFI

( An assessment of the degree to which the objectives of the RFI were achieved;

A A detailed discussion of the type of contamination at the facility, including discussion of the physical, chemical, and toxicological properties of the contaminants;

a A detailed discussion of the results of the investigation. This discussion should discuss the findings for each environmental medium examined;

- Identification of actual and potential human and environmental receptors affected by the release, and an assessment of the risk posed to these receptors;

- A discussion of the concerns of the local community that were identified through the public involvement plan;

$\square$ A listing of any action levels set for the investigation, and comparison of these levels to actual contaminant concentrations;

a Identification and justification of the owner or operator's recommen- dations regarding further action at the site (although the determination for further action is made by the regulator, the opinion of the owner or operator should be in the report); and

$\square$ Appendices (e.g., raw data, pertinent documents).

\section{What decisions are made based on the RFI?}

The findings of the RFI determine that one of the following actions be taken:

Determination of No Further Action is justified for the following reasons: 1) the RFI does not find evidence of a release of hecardous waste or a hazardous constituent from a SWMU, 2) the substance released is not hazardous waste or a hazardous constituent, 3) the release is not from a SWMU, 4) the release is permitted under another authority, 5) the release does not pose a threat to human health or the environment, 6) the release is below the action levels, or 7) the release exceeds action levels but the EPA Administrator or the authorized State Director determines that a CMS is not required.

- ACMS is required if the RFI reveals aneed for correctivemeasures. The following two mechanisms trigger a CMS: 1) the discovery that the waste concentrations in a SWMU exceed the action level set for that contaminant, or 2) EPA or the authorized State determines that the release, even though it does not exceed the applicable action level, is a concern because it poses a threat to human health or the environment [proposed 40 CFR 264.520(a) and (b)].

Note that implementation of interim measures or "stabilization of releases," as called for in EPA's Stabilization Initiative (see Reference 5), can be recommended at any time during the corrective action process. Interim measures are conducted at the facility whenever there may be a significant risk of immediate exposire resulting from releases, when action is required to prevent a release from occurring, or in situations where further migration of a release may result in exposure to human populations or sensitive ecosystems.

\section{What steps are taken after the RFI?}

If the RFI does not find evidence of a release or threatened release, the owner or operator must request a Class 3 final modification of the permit for the facility or request that EPA or the authorized State rescind the RCRA Section 3008(h) Order compelling corrective action, thus ending the RCRA corrective action process. If the RFI identifies the need for corrective measures, the owner or operator is then responsible for performing a CMS. During this step the owner or operator identifies and develops corrective measures alternatives, evaluates the alternatives, and recommends and justifies a remedy. Also, EPA or the authorized State may compel implementation of interim measures in response to immediate threats, such as contamination of drinking water supplies.

Questions of policy or questions requiring policy decisions will not be addressed in EH-231 Information Briefs unless that policy has already been established through appropriate documentation. Please refer any questions concerning the subject matter covered in this Information Brief to Jerry Coalgate, RCRACERCLA Division, EH-231, (202) 586-6075.

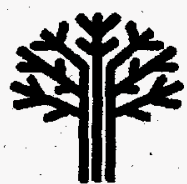

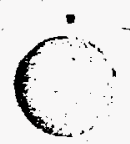

